\title{
Penerapan Manajemen Risiko Perusahaan dan Nilai Perusahaan di Sektor Konstruksi dan Properti
}

\author{
Oka Aditya, Prima Naomi \\ Universitas Paramadina
}

oka.aditya@gmail.com,prima.naomi@paramadina.ac.id

\begin{abstract}
The objective of this study is to emphasize the effect of enterprise risk management (ERM) and control variable i.e: firm size, leverage, profitability, sales growth, shares volatility, and dividend policy toward firm value. This research employs multiple regressions as tool of analysis. The object of this research is construction and property firms that listed on BEI in period 2012-2014. The result of this research showed that ERM and control variable have a significant effect on firm value. However, partially, ERM doesn't have significant effect on firm value. Further more leverage and sales growth variable have significant effect on firm value. The other funding is that size, leverage and dividend policy have significant correlation on ERM.
\end{abstract}

Keywords: enterprise risk management, firm value, multiple linier regressions

\begin{abstract}
Abstrak
Penelitian ini bertujuan untuk menganalisis pengaruh penerapan manajemen risiko perusahaan atau disebut ERM (Enterprise Risk Management) dan variabel kontrol yang terdiri dari ukuran perusahaan, leverage, profitabilitas, pertumbuhan penjualan, volatilitas harga saham, dan kebijakan deviden. Penelitian ini menggunakan regresi berganda sebagai alat analisis. Objek penelitian ialah perusahaan sektor konstruksi dan property yang terdaftar di Bursa Efek Indonesia pada periode 2012-2014. Hasil penelitian menunjukkan bahwa secara bersama-sama ERM dan variabel kontrol yang terdiri dari ukuran perusahaan, leverage, profitabilitas, pertumbuhan penjualan, volatilitas harga saham, dan kebijakan deviden berpengaruh signifikan terhadap nilai perusahaan, namun secara parsial, ERM tidak berpengaruh signifikan terhadap nilai perusahaan. Sedangkan leverage dan pertumbuhan penjualan berpengaruh signifikan terhadap nilai perusahaan. Hasil lain yang ditemukan adalah ukuran perusahaan, leverage dan kebijakan dividen memiliki korelasi signifikan dengan ERM.
\end{abstract}

Kata kunci: manajemen risiko perusahaan, nilai perusahaan, regresi linier berganda

Diterima: 27 Februari 2017; Direvisi: 28 Maret 2017; Disetujui: 25 April 2017 


\section{PENDAHULUAN}

Skandal keuangan besar yang menimpa Enron dan WorldCom pernah mengejutkan publik. Di atas kertas, laporan keuangan sungguh baik tapi pada suatu saat tiba-tiba perusahaan itu kolaps. Hal yang lebih mengejutkan adalah kebangkrutan ini di sebabkan oleh kesalahan fatal dalam sistem akuntansi mereka. Selama tujuh tahun terakhir sebelum terbongkarnya kasus tersebut, Enron melakukan pencatatan berlebihan terhadap laba bersih dan menutupi hutang yang dimiliki. Skandal kedua adalah Worldcom, setelah mengakuisisi MCI, UUNet, Compuserve, dan jaringan data AOL (American Online) pada tahun 1998. Hal itu justru membuat terlalu besarnya kapasitas telekomunikasi dan setelah itu terjadi dot-com bubble pada tahun 2000. Hal ini berimbas pada pendapatan Worldcom yang menurun drastis. Hal ini yang memotivasi Bernard Ebbers sebagai CEO dan Scott Sullivan sebagai CFO dan David Myers sebagai auditor senior memutuskan untuk memanipulasi laporan keuangan. Kasus yang menimpa kedua perusahaan yang melibatkan kantor akuntan publik terkenal Arthur Anderson tersebut sangat mengejutkan para pengguna laporan keuangan di seluruh dunia. Bachtiar (2012) mencatat beberapa perusahaan Indonesia yang pernah terlibat skandal keuangan. Dua perusahaan Indonesia itu adalah Bank Global di tahun 2004 dan PT. KAI di tahun 2006.

Pengalaman skandal akuntansi diatas, memberikan pelajaran bahwa meskipun laporan keuangan secara rutin telah diterbitkan bukanlah berarti sebuah perusahaan telah bebas dari risiko yang mengintai.Pengelolaan risiko menjadi perhatian mendasar dalam era global saat ini. Hal ini disebabkan karena pada era global, bisnis dihadapkan pada lingkungan dengan ketidakpastian dan komplekstitas yang sangat tinggi. Berdasarkan survei yang dilakukan oleh salah satu perusahaan auditor yaitu KPMG terhadap 1500 anggota Komite Audit di 34 negara, ditemukan bahwa 43 persen dari koresponden mengakui betapa semakin sulitnya mengawasi sejumlah risiko utama yang dihadapi oleh perusahaan. Sejumlah risiko utama yang dimaksud antara lain seperti risiko hukum/kepatuhan pada peraturan, korupsi/anti-suap, risiko keuangan, dan/atau risiko IT dan cyber risk. Hal tersebut tidak terlepas dari semakin kompleksnya lingkungan regulasi, bisnis, dan operasional yang dihadapi oleh perusahaan di berbagai dunia (Saputra, 2014). 
Pada awal perkembangannya, perspektif manajemen risiko berbasis silo (parsial) yang dikenal juga sebagai Traditional Risk Managementn (TRM). Pada pendekatan tradisional masih kental dengan ego-sektoral, dimana setiap divisi atau departemen tidak mau saling berbagi informasi atau hal lain yang sebenarnya dibutuhkan untuk kemajuan bersama. Dalam beberapa tahun terakhir, telah terjadi pergeseran paradigma mengenai cara melihat manajemen risiko, dengan menggunakan pendekatan yang holistik. Pendekatan manajemen risiko yang menjadikan pengelolaan risiko melingkupi semua aspek dan dilaksanakan secara terpadu, yang biasa disebut manajemen risiko perusahaan (Enterprise Risk Management). ERM ini berkebalikan dengan TRM. ERM sering disebut juga dengan Integrated Risk Management (IRM) dan Strategic Risk Management (SRM) yang menawarkan sebuah konsep menganggap seluruh portofolio risiko perusahaan secara terpadu dan holistik, dengan demikian mitigasi risiko bisa sejak dini dan komprehensif. Lebih lanjut pengelolaan risiko merupakan bagian dari strategi bisnis secara keseluruhan dan dimaksudkan untuk berkontribusi melindungi dan meningkatkan nilai pemegang saham (Hoyt \& Liebenberg, 2011). Manajemen risiko biasanya dilaksanakan oleh sebuah tim yang disebut Komite Manajemen Risiko.

Di Indonesia, isu tentang pentingnya pengelolaan risiko menjadi perhatian serius, terutama pada industri perbankan. Hal ini dapat dilihat dengan terbitnya Peraturan BI Nomor 8/4/PBI/2006 yang diperbarui oleh Peraturan BI No. 8/14/2006 tentang Pelaksanaan Good Corporate Governance (BI, 2006). Peraturan ini mewajibkan Bank Umum untuk membentuk Komite Pemantau Risiko, diperkuat lagi oleh Otoritas Jasa Keuangan (OJK) melalui Peraturan nomor 18/POJK.03/2016 mewajibkan Bank Umum untuk membentuk Komite Manajemen Risiko (OJK, 2016), sehingga dapat dipastikan semua Bank Umum yang ada di Indonesia telah memiliki Komite Manajemen Risiko. Peraturan tersebut hanya berlaku pada sektor perbankan dan belum menyentuh sektor industri lainnya, padahal risiko dihadapi pada semua bisnis pada sektor industri apapun.

Di Indonesia, pembangunan infrastruktur saat ini gencar dilakukan oleh Pemerintah di bawah kepemimpinan Presiden Joko Widodo. Hal ini, membuat sektor konstruksi menjadi salah satu sektor yang mendukung pertumbuhan 
ekonomi Indonesia. Industri konstruksi tumbuh 7-7.3 persen (Bappenas, 2016). Pasar konstruksi diproyeksikan tumbuh sebesar 14.26\% mencapai Rp 446 triliun pada tahun 2015 dan akan menjadi salah satu sektor yang paling menjanjikan berkat percepatan rencana pembangunan infrastruktur pemerintah (Willantdavis, 2015). Sektor konstruksi diproyeksikan menjadi motor pendorong pertumbuhan ekonomi dan indeks harga saham gabungan pada 2016. Dengan terdorongnya sektor konstruksi, sektor perbankan otomatis terangkat pernyaluran pinjaman kepada proyek-proyek infrastruktur.

Besarnya peran dan risiko bisnis sektor konstruksi dan properti ini, harus diiringi dengan pengelolaan risiko yang memadai. Namun hingga saat ini, belum ada regulasi yang mewajibkan perusahaan pada sektor konstruksi dan properti untuk melakukan pengelolaan risiko sebagaimana regulasi yang ada pada sektor perbankan. Satu-satunya regulasi yang lintas sektoral tentang hal tersebut adalah regulasi tentang pembentukan komite pemantau risiko pada BUMN. Sesuai peraturan Menteri Negara Badan Usaha Milik Negara Nomor: PER-10/MBU/2012 tentang Organ Pendukung Dewan Komisaris/Dewan Pengawas BUMN sehingga semua Badan Usaha Milik Negara (BUMN) telah membentuk Komite Pemantau Manajemen Risiko. Jadi, peraturan tersebut juga berlaku pada BUMN yang bergerak di bidang konstruksi dan properti.

Walaupun perhatian terhadap manajemen risiko meningkat, namun riset akademik dibidang ini masih tergolong minim. Salah satu alasan yang mengemuka adalah karena kesulitan untuk menentukan ukuran yang tepat mengenai konstruksi ERM. Beberapa peneliti (Beasley, dkk, 2008; Hoyt, Liebenberg, 2011) menggunakan kehadiran chief risk officer (CRO) sebagai proxy dari penerapan ERM. Peneliti lain, seperti Gordon, Loeb, dan Tseng mengembangkan index ERM mereka sendiri (Gordon, dkk, 2009).

Penerapan sistem ERM akan meningkatkan kinerja perusahaan (Hoyt \& Liebenberg, 2011). Setidaknya ada tiga penelitian yang mengaitkan ERM dengan performa perusahaan, yang pertama dilakukan oleh Hoyt, Moore, dan Liepenberg (2008), yang kedua dilakukan oleh Gordon, dkk (2009), kemudian yang ketiga yang dilakukan oleh Bertinetti, dkk (2013). Hoyt, dkk (2008) melalui penelitiannya 
meyakini bahwa ada relasi yang positif antara nilai perusahaan dengan penerapan ERM pada perusahaan tersebut. Penelitiannya pada perusahaan asuransi di Amerika Serikat secara statistik dan ekonomi ditemukan nilai perusahaan meningkat hingga $17 \%$ dengan penerapan ERM.

Hasil penerapan ERM bagi perusahaan adalah dengan menurunnya volatilitas pendapatan dan harga saham, meningkatkan efisiensi modal, dan menciptakan sinergi antara aktifitas manajemen risiko yang berbeda (Miccolis \& Shah., 2000; Cumming \& Hirtle, 2001; Lam, 2001; Meulbroek, 2002; Beasley, dkk, 2008). Penerapan ERM nampaknya mempromosikan kepekaan terhadap risiko (risk awareness), dimana hal itu mendukung operasional yang lebih baik dan pengambilan keputusan strategis perusahaan.

Tujuan penelitian ini adalah untuk menemukan bukti empiris atas hal-hal sebagai berikut: Pertama, menganalisis pengaruh penerapan ERM terhadap nilai perusahaan kontruksi dan properti di Indonesia; Kedua, menganalisis pengaruh faktor kontrol yang terdiri dari size, leverage, profitabilitas, volatilitas harga saham, pertumbuhan penjualan, dan kebijakan deviden terhadap nilai perusahaan konstruksi dan properti di Indonesia; Ketiga, menganalisis korelasi Enterprise Risk Management (ERM) dengan variabel kontrol yang terdiri dari size, leverage, profitabilitas, volatilitas harga saham, pertumbuhan penjualan, dan kebijakan deviden.

\section{METODE}

Obyek penelitian adalah perusahan konstruksi dan properti yang terdaftar di BEI. Metode pengambilan sampel yang digunakan adalah purposive sample. Adapun kriteria yang digunakan dalam pengambilan sampel penelitian ini adalah sebagai berikut: (1) Perusahaan sektor kontruksi dan properti yang terdaftar di BEI; (2) Perusahaan sektor konstruksi dan properti tersebut memiliki laporan keuangan lengkap dalam periode 2012, 2013, dan 2014; (3) Perusahaan sektor konstruksi dan properti tersebut memiliki laporan keuangan yang variabelnya dibutuhkan dalam penelitian ini.

Nilai perusahaan $\mathrm{Q}$ adalah variabel terikat (dependent), penerapan ERM merupakan variable independen, serta enam variabel yang lain: size, leverage, 
profitabilitas, volatilitas harga saham, pertumbuhan penjualan, dan kebijakan deviden, adalah variabel kontrol. Penelitian ini akan menggunakan teknik analisis regresi linier berganda. Model penelitian dapat dirumuskan sebagai berikut:

$$
\begin{gathered}
Q=\alpha+\beta_{1} \text { ERM }+\beta_{2} \text { SIZE }+\beta_{3} L E V+\beta_{4} \text { PROF }+\beta_{5} \text { SHARESVOL }+ \\
\beta_{6} \text { SALESGROWTH }+\beta_{7} \text { DIVPOLICY }+\varepsilon
\end{gathered}
$$

Dimana:

Q : nilai perusahaan, dimana diukur dengan Tobin's Q:

$$
Q=\frac{M V E+B V L}{B V A}
$$

MVE : closing price saham diakhir tahun dikalikan volume saham beredar BVL : nilai buku dari total kewajiban

BVA : nilai buku dari total asset

ERM merupakan pengungkapan Manajemen Risiko Perusahaan (ERM) yang tercantum dalam laporan tahunan perusahaan. Penilaian pada variabel ini menggunakan dummy, jika perusahaan menerapkan ERM maka nilainya adalah 1 (satu) dan jika tidak menerapkan makan nilainya 0 (nol).

Ukuran perusahaan: diukur dengan menggunakanjumlah aset yang dimiliki perusahaan pada masing-masing tahun (2010-2013), dengan indikator empirik natural log book value of total assets.

Leverage diukur dari nilai debt to equity ratio (DER) merupakan perbandingan antara jumlah hutang jangka panjang dengan modal sendiri atau ekuitas dalam pendanaan perusahaan.

Profitabilitas diukur dengan return of asset (ROA)

Pertumbuhan penjualan (sales growth), menggunakan pendapatan perusahaan (revenue growth) setiap tahun yang tercantum pada laporan tahunan.

Volatilitas harga saham diukur dengan menggunakan standar deviasi dari data harga saham bulanan masing-masing perusahaan.

Kebijakan dividen diukur dengan mengunakan dummy, nilai satu (1) bagi perusahaan yang membayarkan dividen kepada para pemegang sahamnya dan nol (0) untuk perusahaan yang tidak membayarkan dividen. 


\section{HASIL DAN PEMBAHASAN}

Sesuai dengn kriteria pegambilan sampel jumlah sampel yang terpilih dari 60 perusahaan sektor konstruksi dan property yang terdaftar di BEI hanya 46 yang lolos seleksi kriteria. Data yang digunakan data dari 2012 hingga 2014, sehingga total 138 data terkumpul dan 1 data yang outlier sehingga digunakan 137 data.

Tabel 1. Deskripsi Statistik

\begin{tabular}{lrrrrrrrr}
\hline & \multicolumn{1}{c}{ Q } & ERM & \multicolumn{1}{c}{ SIZE } & VSHARE & LEV & SGROWTH & ROA & DIV \\
\hline Mean & 1.159 & 0.146 & 28.729 & 0.489 & 1.058 & 0.443 & 0.060 & 0.489 \\
Maximum & 11.091 & 1.000 & 31.262 & 2.699 & 5.670 & 11.969 & 0.254 & 1.000 \\
Minimum & 0.118 & 0.000 & 25.249 & 0.028 & 0.002 & -0.871 & -0.088 & 0.000 \\
Std. Dev. & 1.505 & 0.354 & 1.423 & 0.374 & 1.076 & 1.281 & 0.058 & 0.502 \\
Observations & 137 & 137 & 137 & 137 & 137 & 137 & 137 & 137 \\
\hline
\end{tabular}

Pada tabel 1 dapat dilihat nilai perusahaan (Q) paling kecil pada angka 0.117526, nilai paling besar pada 11.09136. Jumlah perusahaan yang menerapkan ERM berjumlah 7 dan sisanya 38 perusahaan tidak menerapakan.Tujuh perusahaan yang menerapkan ERM tersebut terdiri dari 4 BUMN dan 3 swasta.

Table 2. Hasil Regresi

\begin{tabular}{crcrl}
\hline Variable & Coefficient & Std. Error & t-Statistic & Prob. \\
\hline C & -3.6441 & 1.4748 & -2.4709 & 0.0148 \\
\hline ERM & -0.2448 & 0.2315 & -1.0576 & 0.2922 \\
VSHARE & 0.2940 & 0.1748 & 1.6823 & 0.0949 \\
SIZE & 0.1005 & 0.0528 & 1.9046 & 0.0591 \\
SGROWTH & 0.1495 & 0.0499 & 2.9943 & 0.0033 \\
ROA & 0.3410 & 1.2468 & 0.2735 & 0.7849 \\
LEV & 0.3191 & 0.0788 & 4.0513 & 0.0001 \\
DIV & -0.0402 & 0.1548 & -0.2595 & 0.7956 \\
\hline R-squared & 0.2528 & F-statistic & & 6.2336 \\
Adjusted R-squared & 0.2122 & Prob(F-statistic) & & 0.0000 \\
\hline (sumber: data diolah) & \multicolumn{5}{l}{}
\end{tabular}

Uji hipotesis menggunakan regresi berganda dengan metode least squares. Selengkapnya mengenai hasil uji ini dapat dilihat pada Tabel 2. Tabel 2. menunjukkan bahwa nilai $\mathrm{R}^{2}$ sebesar 0,2527 dimana berarti sebesar 25,27\% variasi variabel dependen (nilai perusahaan, Q) dapat dijelaskan oleh variasi variabel independen (ERM) dan variabel kontrol (LEV, Size, ROA, Shares Volatility, Sales Growth, dan Dividend Policy) dalam penelitian ini, sedangkan sisanya yang sebesar 
$74,7242 \%$ dijelaskan oleh variabel lain yang tidak dimasukkan ke dalam penelitian. Nilai probabilitas (F-statistic) adalah 0,0000 di bawah 0,05 , sehingga model dinyatakan sebagai model yang layak.

Hasil koefisien regresi menunjukkan bahwa penerapan enterprise risk management di perusahaan sektor konstruksi dan property tidak berpengaruh siginifikan terhadap nilai perusahaan pada taraf signifikansi 5\%. Begitu pula dengan volatilitas harga saham, ukuran perusahaan (size), profitabilitas (ROA) dan kebijakan deviden semuanya tidak berpengaruh signifikan. Sedangkan variabel leverage dan pertumbuhan penjualan berpengaruh signifikan terhadap nilai perusahaan.

Penerapan manajemen risiko perusahaan (ERM) nampak tidak berpengaruh signifikan terhadap nilai perusahaan. Hal ini senada dengan penelitian yang dilakukan oleh Sanjaya \& Linawati (2015) dimana penerapan ERM pada sektor perbankan tidak berdampak signifikan terhadap nilai perusahaan. Begitu pula penelitian yang dilakukan oleh Saptiti (2013) dengan sampel perusahaan konstruksi dan properti yang terdaftar di BEI tetapi variabel terikatnya adalah kualitas laba, juga tidak menemukan pengaruh yang signifikan dari keberadaan ERM. Hal ini berkebalikan dengan penelitian yang dilakukan di luar negeri oleh Hoyt, dkk (2008) dan Bertinetti, dkk (2013) yang menemukan bahwa penerapan ERM berdampak signifikan terhadap nilai perusahaan. Hal ini kemungkinan disebabkan oleh penerapan ERM di Indonesia masih baru dan masih sebatas pada formalitas mengikuti regulasi yang ada. Sanjaya \& Linawati (2015) yang meneliti pada sektor perbankan di Indonesia juga tidak menunjukkan hasil yang signifikan atas penerapan ERM terhadap nilai perusahaan.

Nilai perusahaan merupakan persepsi investor terhadap potensi pertumbuhan sebuah perusahaan yang sering dikaitkan dengan perkembangan harga saham.Menurut (Salvatore, 2005) harga saham yang tinggi membuat nilai perusahaan juga tinggi dimana tujuan utama perusahaan menurut theory of the firm adalah untuk memaksimumkan kekayaan atau nilai perusahaan.

Hal berbeda dalam hasil penelitian yang dilakukan oleh Manasikana (2015), dengan subyek penelitian terhadap perusahaan manufaktur yang terdaftar di BEI 
pada periode 2010-2013 ditemukan hubungan yang positif signifikan dengan penerapan ERM. Ternyata sektor manufaktur memberikan umpan balik yang berbeda dengan sektor jasa, baik kontruksi-properti maupun perbankan. Keharusan menjaga rantai suplai (supply chain) dan standar kualitas pada setiap produk massal nampaknya menjadi alasan bahwa penerapan ERM menjadi lebih penting dan berdampak pada nilai perusahaan.

Dalam sektor jasa konstruksi-properti ini leverage menjadi variabel yang berpengaruh positif signifikan terhadap nilai perusahaan. Berbeda dengan hasil penelitian oleh Sanjaya \& Linawati (2015) pada sektor perbankan dimana leverage berpengaruh negatif signifikan, yang artinya semakin tinggi leverage akan menurunkan nilai perusahaan. Hal ini berkebalikan dengan sektor konstruksi dan properti dimana leverage tinggi justru meningkatkan nilai perusahaan. Besarnya kewajiban beban bunga yang harus dibayarkan oleh perusahaan konstruksi dan properti justru meningkatkan gairah investor dalam menaruh dananya pada sektor ini. Keyakinan publik akan nilai properti yang pasti naik melampaui beban bunga nampaknya menjadi faktor terkait hal ini. Pertumbuhan pendapatan menjadi variabel kedua yang memiliki hubungan positif dan signifikan terhadap nilai perusahaan. Seperti disebutkan di atas, keyakinan publik atas bisnis jasa properti yang terus tumbuh terbukti disini. Variabel pertumbuhan pendapatan menjadi raja terhadap persepsi investor atas nilai perusahaan. Pertumbuhan yang pesat pada sektor properti sempat dikhawatirkan menyebabkan terjadinya property bubble dan nampaknya hal itu tidak terjadi, sektor ini masih terus tumbuh pesat.

Menurut Sambora, dkk (2014) menyatakan bahwa leverage yang semakin besar merefleksikan semakin kecilnya potensi laba dan dividen yang akan dibagikan kepada pemegang saham, sehingga dapat menurunkan harga saham perusahaan. Penurunan dividen dan harga saham mengakibatkan berkurangnya kepercayaan investor terhadap perusahaan. Dari kasus di atas nampak bahwa leverage dan dividen menjadi hal yang berkebalikan. Menariknya, pada penelitian kali ini ERM berada pada korelasi yang signifikan terhadap keduanya. Dengan demikian dapat dinyatakan bahwa pada perusahaan sektor konstruksi dan properti keberadaan ERM mendukung besarnya leverage, berbeda dengan perusahaan industri makanan 
dan minuman seperti yang diteliti oleh Sambora, dkk (2014).

Leverage merupakan suatu ukuran yang menunjukkan sejauh mana fixed income securities (utang dan saham preferen) digunakan dalam struktur modal perusahaan. Dalam hubungan dengan nilai perusahaan, tanda pada variabel ini ambigu. Di satu sisi, leverage keuangan meningkatkan nilai perusahaan sejauh bahwa hal itu mengurangi arus kas bebas,atau malah mungkin sebaliknya, telah diinvestasikan oleh manajemen dalam proyek yang tidak optimal (Jensen, 1976). Pagach dan Warr (2007) dalam penelitiannya juga menemukan kenaikan $10 \%$ pada leverage meningkatkan 7,8\% kemungkinan perusahaan untuk mempekerjakan CRO. Disisi lain, Liebenberg dan Hoyt $(2008,2011)$ menemukan adanya hubungan negatif antara leverage dengan nilai perusahaan, dimana semakin besar leverage akan mengakibatkan turunnya nilai perusahaan.

Selanjutnya, untuk menjawab tujuan ketiga penelitian ini, yakni mengetahui hubungan variabel lain dengan variabel ERM, maka dilakukan uji korelasi, yang hasilnya dapat dilihat pada tabel 3.

Tabel 3. Hasil Uji Korelasi

\begin{tabular}{lcrrrrrrr}
\hline & Q & \multicolumn{1}{c}{ ROA } & SGROWTH & \multicolumn{1}{c}{ SIZE } & VSHARE & LEV & ERM & \multicolumn{1}{c}{ DIV } \\
\hline Q & 1 & -0.0322 & 0.39542 & -0.0653 & 0.05691 & 0.10833 & 0.02570 & -0.0613 \\
ROA & & 1 & -0.0441 & 0.29914 & 0.20875 & -0.0134 & -0.1543 & 0.29618 \\
SGROWTH & & & 1 & -0.0820 & 0.05891 & -0.1298 & -0.0706 & -0.1333 \\
SIZE & & & & 1 & 0.01943 & 0.34393 & $0.3128^{*}$ & 0.44144 \\
VSHARE & & & & & 1 & 0.09612 & -0.0244 & 0.1244 \\
LEV & & & & & & 1 & $0.5969^{*}$ & 0.44103 \\
ERM & & & & & & & 1 & $0.2985^{*}$ \\
DIV & & & & & & & & 1 \\
\hline
\end{tabular}

Tabel 3 menunjukkan bahwa keberadaan ERM pada perusahaan sektor konstruksi dan properti memiliki korelasi signifikan dengan leverage $(0,597)$, ukuran perusahaan $(0,313)$, dan kebijakan dividen $(0,298)$. Ada dua hal yang bisa dilihat dari hubungan ERM dengan leverage, pertama dengan adanya ERM perusahaan lebih mampu mengelola pinjaman dengan lebih baik atau yang kedua dengan adanya ERM membuat pihak kreditur lebih percaya memberikan pinjaman kepada perusahaan.Ukuran perusahaan juga memiliki korelasi dengan adanya ERM, hal ini semakin besar perusahaan ternyata memiliki kebutuhan pengelolaan risiko yang lebih integratif sehingga membutuhkan ERM. Perusahaan dengan ERM juga punya kecenderungan untuk membayar dividen kepada pemegang sahamnya. 
Secara keseluruhan keberadaan ERM memiliki dampak positif bagi perusahaan dengan memberikan sinyal baik bagi para kreditur dan para investor.

ERM dapat dimaknai sebagai sebuah penerapan manajemen risiko yang menyeluruh, mendetail, dan terintegrasi pada perusahaan. ERM diharapkan dapat mendukung pencapaian tujuan perusahaan melalui pengelolaan terhadap risikorisiko perusahaan (Charvin, 2014). ERM adalah sebuah proses yang melibatkan dewan direksi, manajemen dan anggota perusahaan, yang diimplementasikan dalam pengaturan strategi di seluruh bagian perusahaan. ERM dirancang untuk mengidentifikasi kejadian potensial yang dapat mempengaruhi perusahaan, dan mengelola risiko agar berada pada tingkat risiko yang dapat dikontrol oleh perusahaan, untuk memberikan keyakinan terhadap pencapaian tujuan perusahaan.

ERM mengendalikan risiko yang dihadapi perusahaan secara terintegrasi dan holistik. Kegagalan dalam mengidentifikasi, menilai, dan mengelola risiko dapat mengakibatkan kerugian bagi stakeholder dan shareholder. Selain itu, ERM dapat membantu perusahaan mencapai tujuan utamanya dan menciptakan nilai melalui penerapan ERM yang dikaitkan langsung dengan penyusunan strategi perusahaan. ERM kualitas tinggi dapat mempengaruhi alokasi sumber daya melalui persepsi pelaku pasar dari keandalan laba akuntansi (Baxter, dkk, 2012). Nocco \& Stulz (2006) menyatakan bahwa ERM dapat meningkatkan nilai perusahaan dalam level mikro dan makro. ERM menciptakan nilai dengan memungkinkan manajemen senior untuk mengukur dan mengelola risiko. ERM membantu perusahaan mempertahankan akses ke pasar modal dan sumber daya lain yang diperlukan untuk menerapkan strategi dan rencana bisnis.

Secara umum peran ERM diharapkan akan lebih besar dari yang ada saat ini, seiring semakin berkembangnya perusahaan-perusahaan yang ada di Indonesia dan kemungkinan menyasar pasar global yang lebih luas. Hal itu tentu akan memunculkan tantangan baru dan lebih besar. Tren penerapan ERM nampak positif walau memang belum menggembirakan. Namun, dari laporan tahunan dan rilis berita oleh perusahaan menjadikan penerapan ERM sebagai nilai jual baru (branding) perusahaan kepada investor. 


\section{SIMPULAN}

Berdasarkan hasil pegujian penelitian ini menunjukkan bahwa variabel manajemen risiko perusahaan (ERM) secara tidak berpengaruh signifikan terhadap nilai perusahaan di sektor konstruksi dan properti. Hal ini menunjukkan bahwa penerapan ERM masih sebatas mengikuti regulasi yang ada dan nampak belum berimbas secara langsung pada nilai perusahaan. Lebih dari itu bisa dilihat bahwa penerapan ERM masih baru di Indonesia sedangkan ERM adalah proses strategis yang berkesinambungan. Melihat berbagai kasus perusahaan global yang ada dapat dipastikan penerapan ERM adalah tepat dan harus dijadikan tren positif.

Korelasi ERM terhadap variabel kontrol yang signifikan adalah size, leverage, dan dividen policy. Perusahaan besar risiko semakin besar sehingga penerapan ERM menjadi urgen, juga perusahaan besar lebih memungkinkan untuk melengkapi struktur organisasinya termasuk komite risiko. Semua hal tersebut tercermin pada penelitian kali ini. Yang menarik adalah keberadaan ERM memiliki korelasi positif signifikan dengan leverage, bisa dilihat bahwa keberadaan ERM meyakinkan pihak kreditur untuk memberikan pinjaman pada perusahaanperusahaan di sektor ini. Yang terakhir, perusahaan-perusahaan yang menerapkan ERM nampaknya lebih rajin dalam membagi dividen kepada para investornya, ini sebuah tanda yang positif bagi para investor.

Adapun saran yang bisa diberikan untuk penelitian lebih lanjut adalah: (1) Menggunakan sampel yang lebih banyak dari perusahaan-perusahaan yang terdaftar di Bursa Efek indonesia sehinggahasil yang pengujian lebih menyeluruh atau tergeneralisasi; (2) Menambahkan jumlah tahun penelitian agar dapat melihat pengaruhnyasecara lebih baik. (3) Meneliti pengaruh keberadaan ERM pada sektor industri lain dengan metode yang sama.

\section{PUSTAKA ACUAN}

Bachtiar, E. (2012). Kasus-kasus Etika Bisnis dan Profesi. Jakarta: Salemba Empat. Baxter, R., J.C. Bedard., R. Hoitash., \& A. Yezegel. (2012). Enterprise Risk Management Program Quality: Determinants, Value Relevance, and the Financial Crisis. Contemporery Accounting Research. Vol. 30(4): 12641295. 
Beasley, M., D. Pagach, \& R. Warr. (2008). The Information Conveyed in Hiring Announcements of Senior Executives Overseeing Enterprise-Wide Risk Management Process. Working Paper, North Carolina State University.

Bertinetti, G. S., E. Cavezzali, \& G. Gardenal. (2013). The Effect of The Enterprise Risk Management Implementation on The Frim Value of Europian Companies. Working Paper n. 10/2013, pp. 11-12.

Charvin. (2014, February 22). CRMS knowledge. Retrieved from CRMS Indonesia website: www.crmsindonesia.org. diakses pada 30 Januari 2017

Cumming, C., \& B. Hirtle. (2001). The Challenges of Risk Management in Diversified Financial Companies. FRBNY Economic Policy Review.

Gordon, L. A., M.P. Loeb, \& C.Y. Tseng. (2009). Enterprise Risk Management and Firm Performance: A contingency perspective. Journal of Accounting and Public Policy. Vol. 28 (4): 301-327.

Hoyt, R. E., \& Liebenberg, A. P. (2011). The Value of Enterprise Risk Management. Journal of Risk and Insurance. 78 (4): 795-822.

Hoyt, R. E., Moore, D. L., \& Liebenberg, A. P. (2008). The Value of Enterprise Risk Management: Evidence from the U.S. Insurance Industry. The Society of Actuaries ERM Monograph Paper. diperoleh dari: http://www.soa.org. diakses pada 30 Januari 2017.

Jensen, M. C., \& W.H. Meckling. (1976). Theory of The Firm: Managerial Behavior, Agency Cost and Ownership Structure. Journl of Financial Economics. Vol. 3: 305-360.

Lam, J. (2001). The CRO is Here to Stay. Risk Management. 48 (4): 16-22.

Manasikana, A. (2015). Pengaruh Enterprise Risk Management (ERM) Terhadap Nilai Perusahaan pada Perusahaan Manufaktur yang Terdaftar di Bursa Efek Indonesia Periode 2010-2013. (Skripsi Tidak Dipublikasikan). Surabaya: Universitas Airlangga.

Meulbroek, L. (2002). Integrated Risk Management for the Firm: A Senior Manager's Guide. Journal of Applied Corporate Finance. Vol. 14: 56-70.

Miccolis, J., \& S. Shah. (2000). Enterprise Risk Management: An Analytic Approach. Tillinghast-Towers Perrin, Monograph. 
Nocco, B. W. \& R.M. Stulz. (2006). Enterprise Risk Management: Theory and Practice. Journal of Applied Corporate Finance. Vol. 18 (8): 8-20.

Pagach, D., \& R. Warr. (2007). An Empirical Investigation of the Characteristics of Firms Adopting. Working Paper. College of Management, North Carolina University.

Pagach, D. P., \& Warr, R. S. (2010). The Effects of Enterprise Risk Management on Firm Performance. Working Paper. College of Management, North Carolina University.

Salvatore, D. (2005). Managerial Economics. Singapore: Thomson Learning.

Sambora, M. N., Handayani, S. R., \& Rahayu, S. M. (2014). Pengaruh Leverage dan Profitabilitas, Studi pada Perusahaan Food and Beverages yang terdaftar di BEI periode tahun 2009-2012. Jurnal Administrasi Bisnis. Vol. 8 (1): 110 .

Sanjaya, C.K., \& N. Linawati. (2015). Pengaruh Penerapan Enterprise Risk Management dan Variabel Kontrol Terhadap Nilai Perusahaan. Finesta. Vol. 3 (1): 52-57.

Saptiti, A. (2013). Pengaruh Implementasi Peran Komite Audit dan Enterprise Risk Management Terhadap Kualitas Laba. (Skripsi Tidak Dipublikasikan). Jakarta: UIN Syarif Hidayatullah Jakarta.

Saputra, A. G. (2014). CRMS knowledge. Retrieved from CRMS Indonesia: http://crmsindonesia.org/knowledge/crms-articles/tuntutankompetensi-manajemen-risiko-bagi-anggota-komite-audit-di-tingkat-gl. diakses pada 2 Februari 2017.

Willantdavis. (2015). Press Release. diperoleh dari from The Big 5 Construction Indonesia: http://thebig5constructindonesia.com/media/1476/big-5indonesia-bahasa-march.pdf. diakses pada 30 Januari 2017. 